\title{
Tadeusz Truskolaski, Kamil Waligóra
}

Uniwersytet w Białymstoku

e-mails: tadeusz.truskolaski@post.pl; kamilwaligora@tlen.pl

\section{WPLYW POLITYKI SPÓJNOŚCI UNII EUROPEJSKIEJ NA ZMNIEJSZENIE MIĘDZYREGIONALNEJ LUKI ROZWOJOWEJ W POLSCE

IMPACT OF COHESION POLICY OF THE EUROPEAN
UNION ON REDUCTION OF THE INTERREGIONAL
DEVELOPMENT GAP IN POLAND

DOI: $10.15611 /$ sie.2016.2.06

JEL Classification: E63, H70, I30, N14, N74, N94, O18, O20, O30, O47, O52 P41, R42

Streszczenie: Polityka spójności jest jednym z filarów Unii Europejskiej. Kierowana do słabszych gospodarczo regionów, a finansowana przez zamożniejsze, jest narzędziem korygującym rozbieżności społeczno-gospodarcze. Rozpoczęcie kolejnej - w przypadku Polski trzeciej - perspektywy finansowej zachęca do podsumowania oddziaływania polityki spójności na zmniejszanie luki rozwojowej między województwami. W tekście przedstawiono zmiany w polityce spójności Unii Europejskiej zachodzące w kolejnych dekadach XX i XXI wieku, na podstawie dostępnych danych statystycznych oceniono sposób podziału środków między województwa w Polsce w dwóch perspektywach finansowych: 2004-2006 i 2007-2013. Za Strategią lizbońską, w której wskazano trzy kluczowe obszary polityki regionalnej, przyjęto mierniki dotyczące społecznego, ekonomicznego i terytorialnego oddziaływania. W ten sposób określono fragmentaryczną skuteczność podziału środków z budżetu UE między województwa. Wskazano również przyczyny opóźnienia we wdrażaniu funduszy unijnych w perspektywie finansowej UE na lata 2014-2020 i przedstawiono wnioski, które mogą być wykorzystane podczas przygotowywania polityki spójności na lata po 2020 roku. Ostatecznie stwierdzono, iż przyjęte algorytmy podziału środków wspierały obszary już dysponujące przewagami konkurencyjnymi. Zaobserwowano, iż najsilniejsze gospodarczo regiony utrzymały status quo, a słabsze oddaliły się od średniej dla kraju. Cele polityki spójności osiągnięto w niewielkim stopniu, co powinno wpłynąć na przyszłą zmianę kryteriów alokacji dofinansowania. Stwierdzono, iż kluczowym problemem we wdrażaniu funduszy europejskich staje się biurokratyzacja. Konieczna jest więc symplifikacja procedur umożliwiająca sprawniejsze i skuteczniejsze wydatkowanie środków europejskich.

Słowa kluczowe: konwergencja, polityka regionalna, algorytm, PKB, bezrobocie.

Summary: Cohesion policy is one of the pillars of the European Union. Dedicated to economically weaker regions and funded by the affluent ones, it is a tool for correcting socioeconomic discrepancies. Starting the next - in the case of Poland the third - financial perspective encourages to summarize the impact of cohesion policy on reducing the development gap among the voivodeships. The first part of the paper presents the changes that 
have taken place in the cohesion policy of the European Union in the 20th and 21st century. Then, on the basis of available statistical data the author assessed the way of distribution of funds among the voivodeships in Poland in over two financial perspectives: 2004-2006 and 2007-2013. As in the Lisbon Strategy, which identified three key areas of regional policy, the author adopted measures on social, economic and territorial impact. In this manner fragmentary efficiency of the allocation of funds from the EU budget between the voivodeships was specified. The causes of delay in implementing European funds in financial perspective 2014-2020 were also identified. Finally, the conclusions that can be used in the preparation of cohesion policy for the period after 2020 were presented. It was concluded that the adopted algorithms for the allocation of funds supported the areas already possessing competitive advantages. It has been observed that the strongest economic regions have maintained the status quo, and the less developed ones have remained far from the national average. Cohesion policy objectives have been achieved in a relatively small degree, which should affect the future change of criteria for the allocation of funding. Moreover, it was concluded that bureaucracy was becoming the key problem in implementing European funds. It is therefore essential to simplify the procedures in order to enable more efficient spending of the funds.

Keywords: convergence, regional policy, algorithm, GDP, unemployment

\section{Wstęp}

Polityka spójności Unii Europejskiej formalnie jest realizowana w Polsce od 2004 roku. Obecnie, w ramach trzeciej perspektywy finansowej, polskie regiony otrzymują wsparcie umożliwiające poprawę wewnętrznej spójności terytorialnej i społecznej oraz ograniczenie rozbieżności w poziomie życia mieszkańców z różnych części Wspólnoty. Zgodnie z powyższym politykę spójności powinien cechować taki podział środków, aby najsilniejszym wsparciem objęte zostały regiony znajdujące się na znacznie niższym poziomie rozwoju, zamieszkiwane przez społeczności zmagające się z licznymi problemami, które samodzielnie byłyby trudno rozwiązywalne.

Dotychczasowa polityka spójności nie doprowadziła jednak do zmniejszenia luki rozwojowej między polskimi regionami. Zgodnie z przyjętym w ramach UE sposobem klasyfikacji regionów, do 2014 roku szesnaście polskich województw znalazło się w kategorii regionów słabiej rozwiniętych, czyli o PKB per capita niższym niż 75\% średniej PKB per capita dla państw UE.

Polska, w trakcie wdrażania środków europejskich, została objęta procedurą „n+3”, a następnie „n+2”. Związane było to $\mathrm{z}$ niewielkim poziomem doświadczenia beneficjentów i zarządzających projektami europejskimi. Z każdym kolejnym okresem problemy związane z opóźnieniem rozpoczęcia realizacji projektów, a tym samym wykorzystaniem środków europejskich powinny być coraz mniejsze. Ex post można stwierdzić, iż tak nie jest. Ten stan wymaga więc poszukiwania rzeczywistych przyczyn opóźnień we wdrażaniu środków europejskich.

W wyniku wstępnej analizy założono, że przyczyną dotychczasowej niskiej skuteczności w zakresie niwelowania luki rozwojowej między polskimi regionami był niewłaściwy (liniowy) sposób podziału środków w ramach polityki spójności. 
Poza tym przyjęto, iż przyczyną opóźnień w zakresie wdrażania środków europejskich jest rosnąca (w kolejnych perspektywach finansowych) liczba dokumentów dotyczących zasad wydatkowania, co istotnie utrudnia i wydłuża proceduralne aspekty realizacji projektów.

Celem artykułu jest ocena sposobu podziału środków między województwa w Polsce oraz wskazanie na konieczność symplifikacji procedur wdrażania środków europejskich. Założenia osiągnięto, wykorzystując wybrane mierniki społecznego, terytorialnego i ekonomicznego oddziaływania funduszy europejskich. Na wstępie należałoby się jednak odnieść do polityki spójności i jej podstawowych założeń, które zmieniają się wraz z kolejnymi okresami.

\section{Wprowadzenie do polityki spójności Unii Europejskiej}

Jednym z filarów Unii Europejskiej jest polityka spójności (nazywana również polityką regionalną). Jej zadaniem jest zwiększenie spójności ekonomicznej i społecznej między regionami Unii Europejskiej (UE). Cel osiągany jest przez pomoc regionom słabiej rozwiniętym, w których PKB per capita jest niższe niż 75\% średniej państw UE [Rozporządzenie Parlamentu Europejskiego i Rady (UE) NR 1303/2013 z dnia 17 grudnia 2013 r. ... . Otrzymują one wsparcie finansowe w przypadku realizacji projektów przyczyniających się do ograniczenia bądź rozwiązania problemów społeczno-gospodarczych. Poza tym UE wspomaga gospodarki państw członkowskich, finansując programy na rzecz rewitalizacji słabszych sektorów. Te działania, mają przyczynić się do: zmniejszenia różnic w zakresie poziomu życia oraz zrównoważonego rozwoju regionów UE.

Podstawy polityki spójności pojawiły się w traktatach rzymskich z 1957 r. [EUR-lex 1957]. Ustanowione odniesienia nie poskutkowały stworzeniem całościowej strategii. Były jedynie podstawą do działań zaradczych i koordynacji polityk krajowych. Kolejne rozszerzenia Wspólnoty pogłębiały występujące problemy związane $\mathrm{z}$ dysproporcjami w skali zarówno państw, jak i regionów. Dopiero ustanowienie Jednolitego Aktu Europejskiego (1986 rok), pozwoliło na realizację ponadnarodowej polityki strukturalnej [Czykier-Wierzba 2003].

Cele strategiczne polityki regionalnej były wielokrotnie modyfikowane, tak aby skuteczniej rozwiązywać bieżące problemy. Koniec lat 90. XX wieku zachęcał do wspierania rozwoju i dostosowania strukturalnego regionów słabo rozwiniętych, szczególnie obszarów przygranicznych lub dotkniętych upadkiem przemysłu, zwalczania długotrwałego bezrobocia, które coraz częściej dotykało społeczeństwa państw członkowskich UE, pomocy w zatrudnianiu ludzi młodych wiekiem i stażem pracy.

W pierwszym okresie funkcjonowania polityki spójności pomocą objęto gospodarkę rolną, starając się dostosować struktury produkcyjne do coraz wyższych wymogów jakościowych i konkurencji globalnej, oraz ludność wiejską, która nie była w stanie utrzymać się z pracy na roli. W kolejnym okresie (1993-1999) dokonano 
nowej demarkacji, utrzymując podstawowe cele. Dodatkowo wsparciem objęto regiony o niskiej gęstości zaludnienia.

Pierwsze lata XXI wieku i wyzwania związane z postępem technicznym i technologicznym, globalizacją i przemianami w zakresie handlu, kształtu gospodarki światowej wymusiły intensyfikację wsparcia dla regionów opóźnionych w rozwoju, przeciwdziałanie regresowi terenów przemysłowych i odbudowy upadających gałęzi gospodarki oraz rynku pracy, a przede wszystkim poprawy jego elastyczności, m.in. poprzez wzmocnienie programów wspierających kształcenie i przekwalifikowywanie się. W perspektywie 2007-2013 trzy cele miały decydujące znaczenie: konwergencja, konkurencyjność regionalna i zatrudnienie oraz europejska współpraca terytorialna [Komisja Europejska 2007]. W 2004 roku do UE przyjęto 10 krajów, a w 2007 roku kolejne dwa państwa. Gospodarki nowych członków wymagały intensywnego wsparcia, stąd polityka spójności stała się kluczowa dla podtrzymania pozytywnego kierunku zmian na rzecz wizji Europy jednej prędkości [Ołdak 2011].

W perspektywie finansowej 2014-2020 przeprowadzana jest coraz silniejsza decentralizacja wydatkowania środków europejskich. Przesunięcie decyzyjności z poziomu krajowego na regionalny ma podnieść skuteczność realizowanych przedsięwzięć. Poza tym nadal wsparciem będą objęte regiony słabiej rozwinięte. Działania prowadzone z wykorzystaniem dofinansowania z UE mają uatrakcyjnić te obszary, tak by postrzeganie inwestorów i mieszkańców było coraz lepsze. Podstawowym celem UE staje się coraz pełniejsze wykorzystywanie potencjału społecznego. Straty wynikające $\mathrm{z}$ niedopasowania na rynku pracy i występowania zjawiska bezrobocia są bardzo kosztowne i obniżają konkurencyjność całej UE [Markowski 2008].

W perspektywie budżetowej 2014-2020 polityka została doprecyzowana w dokumentach sektorowych. Częściowa ewaluacja strategii Europa 2020 narzuca realizację zadań z zakresu wzmacniania konkurencyjności regionów ponad kwestie odnoszące się do konwergencji. Coraz większe znaczenie mają konkretne polityki np. względem miast, wsi [McCann, Ortega-Argilés 2013]. Miasta, a szczególnie te określane mianem miejskich obszarów funkcjonalnych ośrodków wojewódzkich (MOF OW), odgrywają w tej perspektywie kluczowe znaczenie [Ministerstwo Rozwoju Regionalnego 2013]. Zgodnie z budżetem zatwierdzonym przez Parlament Europejski na lata 2014-2020 regiony i kluczowe miasta europejskie uzyskają szansę na realizację polityki spójności. Na ten cel przeznaczono 325 mld euro [Europe Direct 2014].

W perspektywie finansowej UE na lata 2014-2020 pojawiły się jednak pewne negatywne tendencje, m.in. dotyczące warunków (przede wszystkim ich liczby), które należy spełnić, aby skorzystać ze środków europejskich. Zauważalne jest również stałe zwiększanie liczby dokumentów kodyfikujących warunki i przebieg projektowania rozwiązań. Wzrost biurokratyzacji w ramach polityki spójności negatywnie wpływa na tempo wdrażania środków europejskich, co przekłada się na skuteczność całej polityki. Szczególne wyzwania przed polityką spójności pojawiły się po 2004 roku. Włączenie dziesięciu państw Europy Środkowo-Wschodniej 
znacznie zwiększyło liczbę regionów wymagających wsparcia. PKB per capita (jako średnia dla całej UE) po akcesji nowych państw spadł o prawie połowę, co świadczy o skali problemów i słabości nowych obszarów [Eurostat 2014]. Ówczesny poziom rozwoju 16. polskich województw pozwolił na objęcie ich pełnym wsparciem w zakresie polityki spójności.

\section{Polityki spójności a rozwój polskich regionów w latach 2004-2014}

Przyjęty okres badawczy, tj. lata 2004-2014, obejmuje dwie perspektywy finansowe Unii Europejskiej: 2004-2006 oraz 2007-2013. W obu przypadkach inaczej dystrybuowano i dzielono środki, co przełożyło się na skalę oddziaływania pomocy UE.

Polityka spójności jest dystrybuowana między regiony zależnie od ich poziomu rozwoju, tzn. stawka dofinansowania projektów jest uwarunkowana wielkością PKB. Najwyższe wsparcie otrzymują realizujący projekty w regionach słabiej rozwiniętych (PKB $<75 \%$ średniej w krajach UE), a następnie w regionach przejściowych $(75 \%<$ PKB $<90 \%$ średniej UE). Ostatnią kategorię tworzą regiony lepiej rozwinięte, osiągające ponad $90 \%$ PKB średniego dla państw UE.

W perspektywie finansowej 2004-2006 Polska otrzymała 12,8 mld euro, w tym ponad 8 mld euro w ramach polityki spójności. Podział środków w ramach regionalnego rozdzielnika przedstawia tab. 1 . W tym okresie większość środków była wydat-

Tabela 1. Podział środków unijnych między polskie województwa w latach 2004-2013

\begin{tabular}{|l|c|l|c|c|}
\hline $\begin{array}{c}\text { Zintegrowany Program } \\
\text { Operacyjny Rozwoju } \\
\text { Regionalnego (ZPORR) } \\
\text { (województwo) }\end{array}$ & $\begin{array}{c}\text { Środki } \\
\text { europejskie } \\
\text { nata 2004-2006 } \\
\text { (w mld euro) }\end{array}$ & $\begin{array}{c}\text { Regionalny Program } \\
\text { Operacyjny } \\
\text { (województwo) }\end{array}$ & $\begin{array}{c}\text { Środki europejskie } \\
\text { na lata 2007-2013 } \\
\text { (w mld euro) }\end{array}$ & $\begin{array}{c}\text { Udział województwa } \\
\text { W łącznej puli } \\
\text { środków na lata } \\
\text { 2004-2013 (w \%) }\end{array}$ \\
\hline Dolnośląskie & 0,224 & dolnośląskie & 1,213 & 7 \\
\hline Kujawsko-pomorskie & 0,142 & kujawsko-pomorskie & 0,951 & 6 \\
\hline Lubelskie & 0,201 & lubelskie & 1,155 & 3 \\
\hline Lubuskie & 0,083 & lubuskie & 0,439 & 6 \\
\hline Lódzkie & 0,157 & łódzkie & 1,006 & 11 \\
\hline Małopolskie & 0,185 & małopolskie & 1,290 & 3 \\
\hline Mazowieckie & 0,300 & mazowieckie & 1,831 & 7 \\
\hline Opolskie & 0,077 & opolskie & 0,427 & 4 \\
\hline Podkarpackie & 0,192 & podkarpackie & 1,136 & 5 \\
\hline Podlaskie & 0,110 & podlaskie & 0,636 & 10 \\
\hline Pomorskie & 0,160 & pomorskie & 0,885 & 4 \\
\hline Śląskie & 0,280 & śląskie & 1,747 & 6 \\
\hline Świętokrzyskie & 0,133 & świętokrzyskie & 0,725 & 8 \\
\hline Warmińsko-mazurskie & 0,182 & warmińsko-mazurskie & 1,036 & 5 \\
\hline Wielkopolskie & 0,196 & wielkopolskie & 1,272 & \\
\hline Zachodniopomorskie & 0,140 & zachodniopomorskie & 0,835 & \\
\hline
\end{tabular}

Źródło: opracowanie własne na podstawie [Internet 3; Internet 4]. 
kowana z poziomu krajowego. W latach 2007-2013 regiony uzyskały dedykowane programy, które umożliwiały im samodzielny podział środków. Dostępna pula znacznie się zwiększyła. Środki wydatkowane w ramach regionalnych programów operacyjnych (RPO) stanowiły około jednej czwartej wszystkich udostępnionych Polsce.

Wielkość dostępnej puli środków dla województw w ramach ZPORR była wyliczana na podstawie centralnie przyjętych algorytmów. Kluczowe znaczenie miała liczba ludności w województwie [Mościcki 2006]. W okresie 2007-2013 podstawą podziału dofinansowania były: stopa bezrobocia, PKB per capita, liczba mieszkańców [Ministerstwo Rozwoju Regionalnego 2007].

W latach 2004-2013 najwięcej środków na poziomie regionalnym przekazano województwom: śląskiemu i małopolskiego, a najmniej - lubuskiemu i podlaskiemu. Pięć województw Polski Wschodniej i dwa mniejsze województwa (opolskie i lubuskie) znalazły się w grupie regionów, które kwotowo uzyskały najmniej. Charakteryzowały się one bardzo wysokimi wskaźnikami świadczącymi o istotnych trudnościach społeczno-gospodarczych oraz niską pozycją konkurencyjną [Ministerstwo Rozwoju Regionalnego 2011].

Polityka spójności to przede wszystkim trzy wymiary: społeczny, ekonomiczny, terytorialny [Barcz 2008]. Do oceny zmian pierwszego stosuje się m.in. stopę bezrobocia, drugi definiowany jest przez PKB per capita, a trzeci - dostępność transportowa danego miejsca. Ze względu na dostępność danych i zakres badania wykorzystano wskazane czynniki.

Tabela 2. Stopa bezrobocia w polskich województwach

\begin{tabular}{|l|r|r|r|r|r|r|r|r|r|r|r|}
\hline Województwo & 2004 & 2005 & 2006 & 2007 & 2008 & 2009 & 2010 & 2011 & 2012 & 2013 & 2014 \\
\hline Lódzkie & 102,6 & 101,7 & 99,3 & 100,0 & 96,8 & 98,3 & 98,4 & 103,2 & 104,5 & 105,2 & 103,5 \\
\hline Mazowieckie & 77,4 & 78,4 & 79,7 & 80,4 & 76,8 & 74,4 & 78,2 & 78,4 & 79,9 & 82,8 & 84,2 \\
\hline Małopolskie & 78,9 & 78,4 & 76,4 & 77,7 & 78,9 & 80,2 & 83,9 & 84,0 & 85,1 & 85,8 & 85,1 \\
\hline Śląskie & 88,9 & 88,1 & 85,8 & 82,1 & 72,6 & 77,7 & 80,6 & 81,6 & 82,8 & 84,3 & 84,2 \\
\hline Lubelskie & 93,7 & 96,6 & 104,7 & 116,1 & 117,9 & 106,6 & 105,6 & 105,6 & 106,0 & 107,5 & 110,5 \\
\hline Podkarpackie & 100,5 & 105,1 & 110,8 & 126,8 & 136,8 & 131,4 & 124,2 & 124,0 & 122,4 & 121,6 & 128,1 \\
\hline Podlaskie & 84,7 & 88,6 & 89,9 & 92,9 & 102,1 & 105,8 & 111,3 & 112,8 & 109,7 & 112,7 & 113,2 \\
\hline Świętokrzyskie & 115,8 & 117,0 & 119,6 & 133,0 & 144,2 & 124,8 & 122,6 & 121,6 & 119,4 & 123,9 & 123,7 \\
\hline Lubuskie & 134,7 & 130,7 & 128,4 & 125,0 & 131,6 & 133,9 & 125,0 & 123,2 & 118,7 & 117,2 & 109,6 \\
\hline Wielkopolskie & 83,7 & 83,0 & 79,1 & 69,6 & 67,4 & 76,0 & 74,2 & 72,8 & 73,1 & 71,6 & 66,7 \\
\hline Zachodniopomorskie & 144,7 & 145,5 & 145,3 & 146,4 & 140,0 & 141,3 & 143,5 & 140,8 & 135,8 & 134,3 & 136,0 \\
\hline Dolnośląskie & 117,9 & 117,0 & 112,2 & 101,8 & 105,3 & 105,8 & 105,6 & 99,2 & 100,7 & 97,8 & 91,2 \\
\hline Opolskie & 105,3 & 106,3 & 109,5 & 106,3 & 103,2 & 106,6 & 109,7 & 106,4 & 107,5 & 106,0 & 103,5 \\
\hline Kujawsko-pomorskie & 124,2 & 126,7 & 129,7 & 133,0 & 140,0 & 133,9 & 137,1 & 136,0 & 135,1 & 135,8 & 136,0 \\
\hline Pomorskie & 112,6 & 109,1 & 103,4 & 95,5 & 88,4 & 98,3 & 99,2 & 100,0 & 100,0 & 98,5 & 97,4 \\
\hline Warmińsko-mazurskie & 153,7 & 154,5 & 159,5 & 167,0 & 176,8 & 171,1 & 161,3 & 161,6 & 159,0 & 161,2 & 164,0 \\
\hline
\end{tabular}

* W każdym roku dla Polski = 100; wartość procentowa.

Źródło: opracowanie własne [Internet 1]. 
Zmiany stopy bezrobocia to ważny czynnik uwydatniający wiele problemów społeczno-gospodarczych (tab. 2). Poza bezpośrednim niedopasowaniem na rynku pracy świadczy również o skali pomocy społecznej, a pośrednio - o zadowoleniu i jakości życia. Uznano, iż kluczowe znaczenie ma stosunek stopy bezrobocia w regionie do stopy bezrobocia dla całej Polski w danym roku. Najlepiej ocenione powinny być te województwa, w których procentowy spadek stopy bezrobocia będzie intensywniejszy niż średnia dla kraju.

W tym zestawieniu najgorzej wypadły województwa: lubelskie, podkarpackie, podlaskie, świętokrzyskie, kujawsko-pomorskie i warmińsko-mazurskie. Tam stopa bezrobocia rosła szybciej niż stopa bezrobocia dla Polski lub malała wolniej dla lat o spadkowej stopie bezrobocia. W latach 2004-2014 negatywna zmiana (od stosunku początkowego w 2004 roku do końcowego w 2014 roku) wynosiła odpowiednio: 17, 28, 29, 8, 12, 11\%. Część z tych województw w roku 2004 miała niższą stopę bezrobocia niż występująca w całej Polsce, gdy już na koniec badanego okresu stopa ta była o kilka-, kilkanaście procent wyższa od średniej dla kraju. Pogarszająca się sytuacja na rynku pracy w tych województwach była wynikiem wielu czynników, w tym zmian sektorowych, m.in. w branży rolno-spożywczej [Zieliński 2006]. Przemiany gospodarcze odczuły przede wszystkim osoby zamieszkujące wieś i utrzymujące się z rolnictwa. Ze względu na dotychczasowy profil były to przede wszystkim uprzednio wymienione województwa.

W większości województw zmiana stopy bezrobocia była zbieżna z trendem dla kraju. W takim zestawieniu najgorsze pozycje zajmują województwa Polski Wschodniej, w których skala problemów występująca po przemianach ustrojowych była nieporównywalnie większa niż na innych obszarach. Stopa bezrobocia negatywnie świadczy m.in. o sposobie podziału środków w ramach polityki spójności oraz niskiej skuteczności dotychczasowych programów.

Pozytywną zmianę gospodarczą polskich regionów w latach 2004-2014 obrazuje dynamika wzrostu PKB per capita. Bezpośrednie zmiany, jakie wystąpily w wyniku realizacji projektów z dofinansowaniem UE po 2004 roku, to m.in.: poprawa jakości i dostępności infrastruktury społecznej, realizacja projektów dynamizujących wzrost i rozwój przedsiębiorstw, zwiększenie dostępności przestrzennej województw oraz włączanie ich w trasy transeuropejskie czy aktywność na rzecz poprawy jakości życia i dopasowania kwalifikacji do potrzeb rynku pracy. Spectrum przemian było bardzo zróżnicowane, a strategie były rozległe, co umożliwiło wdrażanie kompleksowych i współuzupełniających się rozwiązań.

Podstawowym miernikiem umożliwiającym określenie poziomu nominalnej konwergencji polskich regionów jest produkt krajowy brutto (PKB). Realizacja polityki spójności powinna więc umożliwić zmniejszenie rozbieżności między regionami w zakresie dochodów per capita i doprowadzić do zbliżenia wszystkich województw do średniej dla Polski (tab. 3). 
Tabela 3. Stosunek PKB per capita województw do PKB per capita Polski (w \%) w latach 2004-2013

\begin{tabular}{|c|c|c|c|c|c|c|c|c|c|c|c|}
\hline $\mathrm{Rc}$ & 2004 & 2005 & 2006 & 2007 & 2008 & 2009 & 2010 & 2011 & 2012 & 2013 & 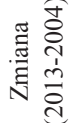 \\
\hline Łódzkie & 92,08 & 92,41 & 92,27 & 92,53 & 93,08 & 92,24 & 2,59 & 92,51 & 93,18 & 93,28 & \\
\hline Mazowieckie & 150,70 & 153,81 & 154,37 & 154,54 & 152,55 & 156,16 & 159,07 & 158,56 & 159,44 & 160,49 & 10 \\
\hline Małopol & 88,48 & 88,55 & 90,08 & 89,10 & 89,66 & 88,87 & 87,70 & 88,82 & 88,29 & 88,70 & 0 \\
\hline Śląskie & 111,73 & 107,80 & 106,12 & 105,61 & 107,25 & 107,27 & 107,12 & 107,42 & 106,07 & 104,04 & -8 \\
\hline Lubelskie & 70,79 & 70,00 & 69,07 & 69,92 & 71,11 & 68,82 & 68,96 & 69,54 & 70,10 & 70,73 & 0 \\
\hline Podkarpackie & 72,69 & 72,10 & 71,49 & 70,48 & 71,67 & 70,52 & 69,61 & 70,19 & 69,89 & 71,08 & -2 \\
\hline Podlaskie & 73,76 & 74,00 & 72,77 & 74,25 & 72,90 & 73,37 & 72,96 & 72,96 & 71,63 & 72,90 & -1 \\
\hline Świętokrzyskie & 79,13 & 76,64 & 78,04 & 79,53 & 82,41 & 78,91 & 77,21 & 76,13 & 74,83 & 72,95 & -6 \\
\hline Lubuskie & 88,85 & 90,62 & 90,00 & 89,37 & 86,86 & 85,33 & 84,51 & 82,94 & 82,95 & 83,14 & -6 \\
\hline Wielkopolskie & 107,21 & 107,87 & 106,45 & 105,68 & 105,78 & 107,88 & 105,14 & 105,13 & 105,88 & 107,24 & 0 \\
\hline Zachodniopomorskie & 90,24 & 90,74 & 90,03 & 88,74 & 89,64 & 86,68 & 85,42 & 83,88 & 83,82 & 83,31 & -7 \\
\hline Dolnośląskie & 101,28 & 103,41 & 107,44 & 108,93 & 108,14 & 108,73 & 112,70 & 113,82 & 113,44 & 111,90 & 11 \\
\hline Opolskie & 85,60 & 83,40 & 81,78 & 84,13 & 86,15 & 83,97 & 82,12 & 81,72 & 80,76 & 80,49 & -5 \\
\hline Kujawsko-po & 88,12 & 86,51 & 86,58 & 86,34 & 85,89 & 83,48 & 82,94 & 81,71 & 81,25 & 81,97 & -6 \\
\hline Pomorskie & 98,25 & 98,91 & 98,74 & 98,60 & 95,64 & 97,69 & 95,99 & 96,03 & 97,76 & 96,33 & -2 \\
\hline Warmińsko-mazurskie & 75,75 & 75,39 & 74,71 & 73,99 & 73,71 & 72,94 & 72,47 & 71,93 & 71,49 & 71,51 & -4 \\
\hline
\end{tabular}

* W każdym roku dla Polski $=100$; wartość procentowa.

Źródło: opracowanie własne na podstawie [Internet 2].

W latach 2004-2014 mieszkańcy całej Polski odczuli pozytywne efekty wzrostu gospodarczego. W tym okresie PKB per capita dla całego kraju wzrósł o ponad $77 \%$. Udział w tej zmianie mieszkańców poszczególnych województw był jednak bardzo różny. Działania podejmowane w ramach polityki spójności powinny prowadzić do zbliżania PKB per capita w poszczególnych województwach do średniej dla całego kraju, czyli regiony, w których ludność zarabia mniej niż średnia, powinny w kolejnych latach zarabiać stosunkowo więcej, a w regionach zamożniejszych wzrost płac powinien być wolniejszy.

Pomoc finansowa skierowana do 16. polskich województw na podstawie m.in. liczby ludności okazuje się nie dość skuteczna. PKB per capita w dwóch regionach (mazowieckie, dolnośląskie) było znacznie wyższe w roku 2013 niż w roku 2004, porównując do średniego dla Polski. W siedmiu województwach (łódzkie, małopolskie, lubelskie, podlaskie, podkarpackie, pomorskie, wielkopolskie) stosunek PKB per capita kraju do PKB per capita województw pozostawał na tym samym poziomie. W pozostałych uległ istotnemu zmniejszeniu, nawet o 8 punktów (śląskie). Dotychczasowy sposób podziału środków okazuje się więc nieskuteczny. Nadal dysproporcja między najbiedniejszymi regionami (lubelskie - 70\% PKB per capita Polski), a najbogatszymi (mazowieckie - 160\% PKB per capita Polski) pozostaje bardzo duża, co uniemożliwia przeciwdziałanie negatywnym trendom, jak np. nad- 
mierna migracja ludności z Polski Wschodniej do Warszawy i większych ośrodków w zachodniej części kraju.

W przypadku realizacji założeń polityki spójności kolejnymi oczekiwanymi miernikami są: nasycenie infrastrukturą transportową (w tym wypadku drogową) oraz - pozostając przy miernikach obrazujących dynamikę zmian - tempo zwiększania kilometrów dróg w stosunku do długości dróg w całej Polsce. W obu przypadkach pominięto kolejnictwo. W przeważającej większości realizowane inwestycje miały na celu odnowienie już funkcjonujących linii, co znacznie nie wpłynęło na możliwość zwiększenia liczby przejazdów. Poza tym nie wzięto pod uwagę również infrastruktury lotniczej. Szczególnie we wschodniej części kraju porty lotnicze, ze względu na wielkość i liczbę obsługiwanych pasażerów, nie stanowią o dostępności przestrzennej danego obszaru. Istotniejsze wydają się połączenia drogowe, szczególnie włączanie poszczególnych województw w trasy o znaczeniu międzynarodowym. Ze względu na względnie niewielką w skali świata powierzchnię Polski i odległości rzędu kilkudziesięciu albo kilkuset kilometrów od istniejących portów lotniczych ważne jest przede wszystkim dobre skomunikowanie tych obszarów.

Tabela 4. Zmiana nasycenia powierzchni województw kilometrami dróg twardych i gruntowych w latach 2004-2014

\begin{tabular}{|c|c|c|c|c|c|c|c|c|c|c|c|c|}
\hline \multirow[b]{3}{*}{$\begin{array}{l}\text { Kraj } \\
\text { /województwo }\end{array}$} & \multicolumn{11}{|c|}{ Stosunek kilometrów dróg (twardych i gruntowych) do powierzchni danego obszaru } & \multirow{3}{*}{ 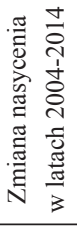 } \\
\hline & 2004 & 2005 & 2006 & 2007 & 2008 & 2009 & 2010 & 2011 & 2012 & 2013 & 2014 & \\
\hline & \multicolumn{11}{|c|}{ [km dróg/km² powierzchni] } & \\
\hline Polska & 1,213 & 1,220 & 1,224 & 1,225 & 1,226 & 1,228 & 1,299 & 1,318 & 1,318 & 1,328 & 1,334 & 0,121 \\
\hline Łódzkie & 1,300 & 1,311 & 1,323 & 1,319 & 1,311 & 1,326 & 1,403 & 1,443 & 1,404 & 1,407 & 1,437 & 0,137 \\
\hline Mazowieckie & 1,372 & 1,403 & 1,408 & 1,405 & 1,399 & 1,418 & 1,471 & 1,496 & 1,491 & 1,496 & 1,503 & 0,132 \\
\hline Małopolskie & 1,857 & 1,870 & 1,875 & 1,885 & 1,886 & 1,850 & 2,000 & 1,994 & 1,998 & 1,973 & 1,980 & 0,123 \\
\hline Śląskie & 2,026 & 2,029 & 2,028 & 2,019 & 2,004 & 2,050 & 2,083 & 2,145 & 2,073 & 2,205 & 2,083 & 0,057 \\
\hline Lubelskie & 1,175 & 1,175 & 1,177 & 1,180 & 1,201 & 1,211 & 1,354 & 1,377 & 1,361 & 1,364 & 1,392 & 0,217 \\
\hline Podkarpackie & 1,015 & 1,024 & 1,030 & 1,032 & 1,034 & 1,020 & 1,029 & 1,060 & 1,077 & 1,133 & 1,160 & 0,145 \\
\hline Podlaskie & 0,954 & 0,970 & 0,976 & 0,970 & 0,967 & 0,988 & 1,199 & 1,267 & 1,251 & 1,304 & 1,312 & 0,358 \\
\hline Świętokrzyskie & 1,395 & 1,433 & 1,421 & 1,423 & 1,434 & 1,437 & 1,444 & 1,461 & 1,466 & 1,416 & 1,467 & 0,072 \\
\hline Lubuskie & 0,928 & 0,937 & 0,946 & 0,958 & 0,948 & 0,906 & 0,945 & 0,974 & 1,034 & 1,071 & 1,060 & 0,133 \\
\hline Wielkopolskie & 1,325 & 1,331 & 1,337 & 1,343 & 1,353 & 1,344 & 1,350 & 1,341 & 1,350 & 1,351 & 1,352 & 0,027 \\
\hline Zachodniopomorskie & 0,787 & 0,765 & 0,772 & 0,780 & 0,784 & 0,793 & 0,826 & 0,833 & 0,860 & 0,861 & 0,860 & 0,073 \\
\hline Dolnośląskie & 1,133 & 1,124 & 1,134 & 1,128 & 1,127 & 1,124 & 1,177 & 1,187 & 1,183 & 1,175 & 1,185 & 0,052 \\
\hline Opolskie & 1,188 & 1,157 & 1,157 & 1,158 & 1,143 & 1,111 & 1,216 & 1,205 & 1,209 & 1,128 & 1,162 & $-0,026$ \\
\hline Kujawsko-pomorskie & 1,362 & 1,390 & 1,392 & 1,390 & 1,399 & 1,411 & 1,473 & 1,476 & 1,485 & 1,489 & 1,487 & 0,125 \\
\hline Pomorskie & 1,086 & 1,082 & 1,082 & 1,085 & 1,086 & 1,109 & 1,220 & 1,230 & 1,239 & 1,280 & 1,269 & 0,183 \\
\hline Warmińsko-mazurskie & 0,895 & 0,896 & 0,890 & 0,895 & 0,893 & 0,882 & 0,934 & 0,955 & 0,948 & 0,933 & 0,948 & 0,053 \\
\hline
\end{tabular}

Źródło: opracowanie własne na podstawie [Internet 2]. 
Szczególnie w latach 2007-2013 znaczna pula środków została skierowana na infrastrukturę drogową. Inwestycje tego typu realizowano z Programu operacyjnego „Infrastruktura i Środowisko" oraz z regionalnych programów operacyjnych. Dodatkowo pięć województw: warmińsko-mazurskie, podlaskie, lubelskie, świętokrzyskie i podkarpackie, mogło również wykorzystać dedykowane środki w ramach Programu operacyjnego „Rozwój Polski Wschodniej”.

W latach 2004-2014 doszło do istotnego wzrostu nasycenia infrastrukturą drogową, w Polsce o ponad 12\% (tab. 4). Największy wzrost odnotowano w województwach: podlaskim, lubelskim, podkarpackim i pomorskim, a najmniejszy w - opolskim, wielkopolskim, dolnośląskim i warmińsko-mazurskim.

Zaprezentowane wskazania należałoby uzupełnić informacjami na temat tempa przyrastania długości dróg w stosunku do wzrostu notowanego dla całej Polski. Im bliżej średniej, tym cele związane z polityką spójności zostały osiągnięte w większym stopniu (tab. 5).

Tabela 5. Zmiana długości $(\mathrm{km})$ dróg publicznych utwardzonych i gruntowych dla poszczególnych województw w stosunku do całej Polski w danym roku

\begin{tabular}{|l|c|c|c|c|c|c|c|c|c|c|c|}
\hline \multirow{2}{*}{$\begin{array}{l}\text { Kraj/ } \\
\text { województwo }\end{array}$} & \multicolumn{8}{|c|}{ Zmiana długości dróg dla poszczególnych województw } \\
\cline { 2 - 15 } & 2004 & 2005 & 2006 & 2007 & 2008 & 2009 & 2010 & 2011 & 2012 & 2013 & 2014 \\
\hline Polska (rok bazowy 2004) & 1,000 & 1,006 & 1,009 & 1,010 & 1,011 & 1,013 & 1,071 & 1,087 & 1,087 & 1,095 & 1,100 \\
\hline Łódzkie & 0,062 & 0,063 & 0,063 & 0,063 & 0,062 & 0,063 & 0,063 & 0,064 & 0,062 & 0,062 & 0,063 \\
\hline Mazowieckie & 0,129 & 0,131 & 0,131 & 0,130 & 0,130 & 0,131 & 0,129 & 0,129 & 0,129 & 0,128 & 0,128 \\
\hline Małopolskie & 0,074 & 0,074 & 0,074 & 0,075 & 0,075 & 0,073 & 0,075 & 0,073 & 0,074 & 0,072 & 0,072 \\
\hline Śląskie & 0,066 & 0,066 & 0,065 & 0,065 & 0,064 & 0,066 & 0,063 & 0,064 & 0,062 & 0,065 & 0,062 \\
\hline Lubelskie & 0,078 & 0,077 & 0,077 & 0,077 & 0,079 & 0,079 & 0,084 & 0,084 & 0,083 & 0,083 & 0,084 \\
\hline Podkarpackie & 0,048 & 0,048 & 0,048 & 0,048 & 0,048 & 0,047 & 0,045 & 0,046 & 0,047 & 0,049 & 0,050 \\
\hline Podlaskie & 0,051 & 0,051 & 0,052 & 0,051 & 0,051 & 0,052 & 0,060 & 0,062 & 0,061 & 0,063 & 0,064 \\
\hline Świętokrzyskie & 0,043 & 0,044 & 0,044 & 0,044 & 0,044 & 0,044 & 0,042 & 0,041 & 0,042 & 0,040 & 0,041 \\
\hline Lubuskie & 0,034 & 0,034 & 0,035 & 0,035 & 0,035 & 0,033 & 0,033 & 0,033 & 0,035 & 0,036 & 0,036 \\
\hline Wielkopolskie & 0,104 & 0,104 & 0,104 & 0,105 & 0,105 & 0,104 & 0,099 & 0,097 & 0,098 & 0,097 & 0,097 \\
\hline Zachodniopomorskie & 0,048 & 0,046 & 0,046 & 0,047 & 0,047 & 0,047 & 0,047 & 0,046 & 0,048 & 0,047 & 0,047 \\
\hline Dolnośląskie & 0,060 & 0,059 & 0,059 & 0,059 & 0,059 & 0,058 & 0,058 & 0,057 & 0,057 & 0,056 & 0,057 \\
\hline Opolskie & 0,029 & 0,029 & 0,028 & 0,028 & 0,028 & 0,027 & 0,028 & 0,028 & 0,028 & 0,026 & 0,026 \\
\hline Kujawsko-pomorskie & 0,065 & 0,065 & 0,065 & 0,065 & 0,066 & 0,066 & 0,065 & 0,064 & 0,065 & 0,064 & 0,064 \\
\hline Pomorskie & 0,052 & 0,052 & 0,052 & 0,052 & 0,052 & 0,053 & 0,055 & 0,055 & 0,055 & 0,056 & 0,056 \\
\hline Warmińsko-mazurskie & 0,057 & 0,057 & 0,056 & 0,057 & 0,056 & 0,056 & 0,056 & 0,056 & 0,056 & 0,054 & 0,055 \\
\hline
\end{tabular}

Źródło: opracowanie własne na podstawie [Internet 2].

W całej Polsce w latach 2004-2014 długość dróg zwiększyła się o ponad 10\%. Dynamika wzrostu liczby km dróg była jednak bardzo zróżnicowana dla poszczególnych województw. Przyjmując stosunek całkowitej długości dróg w województwie w stosunku do km dróg dla Polski w danym roku, zauważa się, że w całym 
okresie zaledwie pięć województw szybciej poprawiało ten parametr. Były to: podlaskie, lubelskie, pomorskie, lubuskie i podkarpackie. W sześciu województwach drogi również powstawały, ale wolniej niż wynosiła średnia dla Polski; były to: małopolskie, śląskie, wielkopolskie, dolnośląskie, świętokrzyskie i opolskie. W większości z nich stopień nasycenia przewyższał średnią dla Polski, co uzasadnia znacznie niższą potrzebę rozbudowy infrastruktury drogowej.

Należy zaznaczyć, że przedstawione zestawienia i dane są jedynie wycinkiem miar, które służą do oceny konkurencyjności regionów. Pełen pomiar skuteczności polityki spójności wymagałby skupienia się również na takich jej elementach, jak: wdrażanie, realizacja, możliwość dostosowania i kreacji itd. Celem prezentowanego ujęcia była przede wszystkim refleksja nad kryteriami podziału środków w ramach polityki spójności.

\section{Polityka spójności w perspektywie 2014-2020}

Skuteczność wydatkowania środków na działania związane ze spójnością w latach 2014-2020 oceniać można będzie po zakończeniu perspektywy. Właściwsze wydaje się zdefiniowanie przyczyn, których wynikiem jest opóźnienie we wdrażaniu środków europejskich.

W bieżącym okresie opóźnienia w rozpoczęciu wdrażania środków europejskich wynoszą od kilkunastu do kilkudziesięciu miesięcy. Instytucje kontrolne zwracały ex ante uwagę na obszary, w ramach których wystąpić mogą opóźnienia [Najwyższa Izba Kontroli 2014]. Lata 2014-2016 to okres, w którym projekty z lat 2007-2013 wyczerpały swój potencjał, a nowe nie zostały jeszcze rozpoczęte. Powoduje to, iż dotychczas realizowane cele nie mają zapewnionego długookresowego wsparcia, a więc może wystąpić regres pozytywnych tendencji. W ramach przyczyn obiektywnych można wskazać na przedłużające się prace nad nową perspektywą w Komisji Europejskiej i europarlamencie. Opóźnienia dotyczyły m.in. pakietów rozporządzeń, zatwierdzenia budżetu, negocjacji programów operacyjnych z Komisją Europejską. Tylko w ramach negocjacji opóźnienie wynosiło ok. 14 miesięcy, podczas gdy w przypadku poprzedniej perspektywy było to ok. 10 miesięcy.

Kolejny problem mający przełożenie na dotychczasowe opóźnienia to warunki wstępne, od których spełnienia zależy uruchomienie środków. W kolejnych perspektywach finansowych jest ich coraz więcej. W aktualnej perspektywie, na lata 2014-2020, było ich aż 29. Stopień biurokratyzacji przenoszonej ze szczebla unijnego na krajowy, a następnie regionalny i lokalny jest więc coraz większy [Gniadowski 2016].

Na poziomie regionalnym jako kluczowe problemy wskazywane są niejasne procedury, skomplikowanie prawa warunkującego pozyskiwanie i wydatkowanie środków, a także niewdrożenie wszystkich oczekiwanych przez Komisję Europejską dyrektyw. Stopień biurokratyzacji to kolejny element bardzo często wskazywany przez przedstawicieli władz regionalnych [PAP 2016]. 
Ministerstwo Rozwoju w ramach przeprowadzonej analizy wskazało przede wszystkim na niewystarczające tempo uruchamiania konkursów i oceny wniosków oraz powolny postęp kontraktacji w regionach. Źródeł tych problemów należy upatrywać w: zbyt długim przebiegu naborów (niewspółmiernym do wielkości środków), dysproporcjach w obsłudze naborów zależnie od województw i funduszu, niskiej jakości naborów oraz podaży projektów, powolnej kontraktacji w regionach [Ministerstwo Rozwoju 2016].

Tabela 6. Ocena stanu realizacji RPO - certyfikacja wydatków do KE wg województw (stan z 31 października 2016 roku)

\begin{tabular}{|l|c|c|}
\hline \multicolumn{1}{|c|}{ Województwo } & $\begin{array}{c}\text { Plan wydatkowania RM na 2016 rok } \\
\text { wydatki kwalifikowalne } \\
\text { podstawa certyfikacji } \\
\text { (w mln zł) }\end{array}$ & $\begin{array}{c}\text { Wykonanie planu } \\
\text { wydatkowania RM } \\
\text { na 2016 rok } \\
\text { (w \%) }\end{array}$ \\
\hline Dolnośląskie & 561,8 & 11,37 \\
\hline Kujawsko-pomorskie & 474,8 & 16,08 \\
\hline Lubelskie & 556,4 & 5,39 \\
\hline Lubuskie & 226,2 & 12,17 \\
\hline Lódzkie & 562,7 & 23,52 \\
\hline Małopolskie & 717,9 & 4,29 \\
\hline Mazowieckie & 714,4 & 12,98 \\
\hline Opolskie & 389,1 & 26,08 \\
\hline Podkarpackie & 527,3 & 7,14 \\
\hline Podlaskie & 302,7 & 8,18 \\
\hline Pomorskie & 600,0 & 11,52 \\
\hline Śląskie & 867,2 & 4,13 \\
\hline Świętokrzyskie & 340,3 & 17,28 \\
\hline Warmińsko-mazurskie & 431,1 & 0,00 \\
\hline Wielkopolskie & 611,1 & 10,37 \\
\hline Zachodniopomorskie & 399,4 & 14,02 \\
\hline
\end{tabular}

* RM - Rada Ministrów.

Źródło: na podstawie prezentacji [Ministerstwo Rozwoju 2016]; dane SL 2014, według stanu z 31 października 2016 roku, wykorzystanie alokacji według g kursu: 1 EUR $=4,3065$ PLN.

Ministerstwo Rozwoju przygotowało również plan naprawczy, w którym uwzględniono m.in. możliwość zmian w ustawie wdrożeniowej (uproszczenia), zwiększenie potencjału kadrowego instytucji zarządzających RPO, poprawę procedur wyboru wniosków oraz przegląd kryteriów formalnych wyboru. Wskazano również na celowość wprowadzenia instrumentów finansowych oraz wsparcia zwrotnego w przypadku obszarów o dużej podaży projektów.

Skupiono się także na kwestiach związanych z jakością wniosków. Główne działania naprawcze będą dotyczyły szkoleń dla wnioskodawców i wzmocnienia punk- 
tów informacyjnych o projektach. Dodatkowo nie będzie zgody na opóźnienia w harmonogramach konkursów oraz przewidziano nagrodę w postaci zwiększenia budżetu w konkursach cechujących się projektami wysokiej jakości. Poprawa wskaźników alokacji ma zostać osiągnięta przez przyspieszenie kontraktacji projektów pozakonkursowych, związanych z uczelniami i jednostkami badawczymi, z polskimi kolejami itd. Poza tym zadeklarowano, iż zakończone będą prace nad zmianami w ustawie wdrożeniowej, przyjęte będą wytyczne w zakresie trybu naborów projektów, ich kwalifikowalności, wsparcia EFS w obszarze zdrowia i edukacji oraz przygotowane zostaną mapy potrzeb zdrowotnych [Ministerstwo Rozwoju 2016].

Należy zauważyć, że nie są to konkretne zmiany, a raczej zapewnienia odnośnie do działania. Nadal nie zostały przygotowane wytyczne, przepisy regulujące charakter współpracy i pozwalające określić jasne kryteria działania. Symplifikacja prawa oraz szybsze wdrażanie wytycznych europejskich na poziomie krajowym przyczyniłyby się do poprawy stopnia wykorzystania środków europejskich. Są to elementy, które bezpośrednio ograniczają korzyści wynikające z otrzymanych możliwości w ramach polityki spójności.

\section{Podsumowanie - polityka spójności w Polsce}

Polityka spójności rozpatrywana w ramach trzech obszarów, z wykorzystaniem mocno uproszczonych wskaźników, pozwoliła na pobieżną ocenę zagadnienia. Ta stanowi punkt wyjściowy do dalszej analizy, która będzie kontynuowana.

Polskie województwa podczas 10 lat (2004-2014) poprawiły swoją pozycję konkurencyjną. Otwarcie europejskiego rynku, wzrost konkurencji itd. przyczyniały się do wdrażania nowych rozwiązań, a te - do rozwoju województw. Polityka spójności miała przede wszystkim redukować lukę występującą między biedniejszymi a zamożniejszymi regionami UE. Ten cel został osiągnięty fragmentarycznie. Część celów szczegółowych, np. obniżenie stopy bezrobocia przez dopasowanie kwalifikacji pracowników do potrzeb rynku pracy, osiągnięto, lecz w niedostatecznym stopniu. Część regionów, ze względu na przyjęty sposób podziału środków, osłabiło swoją konkurencyjność. Rozbieżność między stanem początkowym dla poszczególnych regionów okazała się zbyt duża względem wielkości dostępnej puli środków. W niektórych przypadkach podczas badanych 10 lat doszło do pogłębienia już występujących problemów.

Polityka spójności w obszarze dostępności komunikacyjnej przyniosła najwięcej pozytywnych efektów. Jej prowadzenie zmniejszyło rozbieżności między regionami o niskim nasyceniu infrastrukturą transportową w stosunku do regionów lepiej rozwiniętych. Nie wszystkie regiony Polski Wschodniej w pełni wykorzystały tę szansę (np. warmińsko-mazurskie), jednak postęp na tym polu okazał się największy.

Przy podobnym wsparciu zewnętrznym (np. przy wykorzystaniu środków z budżetu UE) obszary mające wyższy potencjał, silniejszą pozycję konkurencyjną, 
ustrukturyzowane gospodarczo i przede wszystkim większe (w wartościach absolutnych) przechwytują większą część korzyści. Realizacja polityki spójności wymaga więc silniejszego wsparcia słabszych i mniejszych podmiotów, np. w przypadku Polski skupienia się przede wszystkim na Polsce Wschodniej. W ten sposób słabsze gospodarczo regiony uzyskałyby przewagi początkowe, niezbędne do podjęcia rywalizacji i kształtowania warunków wzajemnych relacji. Aktualnie obowiązujący system powodował rozmycie efektów i ograniczał osiągnięcie celu, jakim jest konwergencja (realna, a nie tylko nominalna).

Dotychczasowa stosunkowo niska skuteczność polityki spójności spowodowana była niewłaściwym sposobem podziału środków z budżetu UE między polskie województwa, a opóźnienia w zakresie wdrażania funduszy unijnych, szczególnie w perspektywie 2014-2020, spowodowane są nadmiernymi obciążeniami biurokratycznymi. Symplifikacja przepisów związanych z nadzorowaniem i zarządzaniem środkami europejskimi jest więc niezbędna do skutecznego i sprawnego rozwiązywania problemów mieszkańców UE.

Reasumując, należy stwierdzić, że kontynuacja polityki spójności jest potrzebna. Niewykluczone jednak, że powinna ona być skierowana do regionów o poziomie rozwoju niższym niż przyjęte $75 \%$ PKB per capita średniej UE. Poza tym należałoby stworzyć bloki, np. społeczny, ekonomiczny, terytorialny, w ramach których dany region podlegałby wsparciu bądź nie. Takie zasady uniemożliwiłyby finansowanie regionów, które na danym polu mają już względnie silną pozycję. Poza tym należałoby ograniczyć liczbę dokumentów oraz uprościć procedury, by cały proces podziału i finansowania był transparentny. Ograniczenie tworzenia nowych i uproszczenie (skrócenie) dotychczasowych regulacji mogłoby poprawić skuteczność działań. Wtedy efekty polityki spójności mogłyby być jeszcze intensywniejsze, potwierdzając zarazem wartość, jaką niesie za sobą współpraca w ramach Unii Europejskiej.

Pozytywny wpływ polityki spójności zarówno na stopę bezrobocia, PKB per capita, jak i dostępność komunikacyjną byłby znacznie większy, gdyby skupić się na działaniach zmierzających do realnej konwergencji między regionami. Dozowanie skali środków między regiony powinno być ukierunkowane na konkretne problemy. Dodatkowym finansowaniem powinny być objęte przede wszystkim te najsłabsze. Wtedy miałyby one szanse zbliżenia się do średniej ogólnopolskiej, a dalej nawiązania rywalizacji z silniejszymi regionami. Wieloletnie zaniedbanie, sięgające kilku wieków, powoduje, że regiony na wschód od Wisły mają znacznie słabszą pozycję konkurencyjną niż te położone na zachód od niej. Polityka spójności powinna być więc wykorzystywana do zmniejszania tych dysproporcji, a nie jedynie do ogólnego wsparcia wszystkich podmiotów. 


\section{Literatura}

Barcz J., 2008, Przewodnik po Traktacie z Lizbony. Traktaty stanowiace Unię Europejska. Stan obecny oraz teksty skonsolidowane w brzmieniu Traktatu z Lizbony, Wydawnictwo Prawnicze LexisNexis, Warszawa.

Czykier-Wierzba D., 2003, Finansowanie polityki regionalnej w Unii Europejskiej, Wydawnictwo Twigger, Warszawa.

EUR-lex, 1957, Traktat ustanawiajacy Europejska Wspólnotę Gospodarczq, http://eur-lex.europa.eu/ legal-content/PL/TXT/?uri=CELEX:11957E/TXT (15.04.2016).

Europe Direct, 2014, Zmiany w systemie finansowania polityki spójności w okresie 2014-2020, http:// europedirect-tarnow.europim.pl/zmiany-w-systemie-finansowania-polityki-spojnosci-wokresie-2014-2020 (22.04.2016).

Eurostat, 2014, Produkt Krajowy Brutto w podziale na NUTS 3, http://ec.europa.eu/eurostat/web/products-datasets/-/nama_r_e3gdp (14.04.2016).

Gniadowski A., 2016, Samorzady zbyt wolno wykorzystuja środki unijne, http://www.wspolnota.org.pl/ aktualnosci/aktualnosc/samorzady-zbyt-wolno-wykorzystuja-srodki-unijne/ (14.11.2016).

Komisja Europejska, 2007, Polityka spójności 2007-2013. Komentarze i teksty oficjalne, Urząd Oficjalnych Publikacji Wspólnot Europejskich, Luksemburg, s. 13-26.

Markowski K., 2008, Ekonomiczne aspekty migracji, [w:] Migracja - wyzwanie XXI wieku, Zięba M. (red.), Wydawnictwo Katolickiego Uniwersytetu Lubelskiego, Lublin.

McCann P., Ortega-Argilés R., 2013, Redesigning and reforming European regional policy: The reasons, the logic, and the outcomes, International Regional Science Review, vol. 36, s. 424-445.

Ministerstwo Rozwoju, 2016, Przyspieszenie realizacji programów regionalnych 2014-2020 - Plan działań, prezentacja ze spotkania Ministerstwa Rozwoju z Instytucjami Zarządzającymi Programami Regionalnymi, 9 listopada 2016 r., Warszawa.

Ministerstwo Rozwoju Regionalnego, 2007, Narodowe Strategiczne Ramy Odniesienia 2007-2013 wspierajace wzrost gospodarczy i zatrudnienie. Narodowa Strategia Spójności, Warszawa, 5/2007 r., Warszawa, s. 117-118.

Ministerstwo Rozwoju Regionalnego, 2011, Program Operacyjny Rozwój Polski Wschodniej 2007-2013, Warszawa.

Ministerstwo Rozwoju Regionalnego, 2013, Kryteria delimitacji Miejskich Obszarów Funkcjonalnych Ośrodków Wojewódzkich, Warszawa.

Mościcki B., 2006, Euro dla regionów, Polityka Samorządowa, nr 21(5), s. 21.

Najwyższa Izba Kontroli, 2014, O przygotowaniu Polski do wykorzystania środków UE, https://www. nik.gov.pl/aktualnosci/o-przygotowaniu-polski-do-wykorzystania-srodkow-ue.html, (17.11.2016).

Ołdak A., 2011, Premier Tusk: Europa jednej prędkości, http://www.wnp.pl/drukuj/140175_1.html (28.05.2016).

Polska Agencja Prasowa, 2016, Które województwa najlepiej radza sobie z funduszami unijnymi?, http://www.samorzad.lex.pl/czytaj/-/artykul/ktore-wojewodztwa-najlepiej-radza-sobie-zfunduszami-unijnymi (16.11.2016).

Rozporządzenie Parlamentu Europejskiego i Rady (UE) NR 1303/2013 z dnia 17 grudnia 2013 r. ustanawiające wspólne przepisy dotyczące Europejskiego Funduszu Rozwoju Regionalnego, Europejskiego Funduszu Społecznego, Funduszu Spójności, Europejskiego Funduszu Rolnego na rzecz Rozwoju Obszarów Wiejskich oraz Europejskiego Funduszu Morskiego i Rybackiego oraz ustanawiające przepisy ogólne dotyczące Europejskiego Funduszu Rozwoju Regionalnego, Europejskiego Funduszu Społecznego, Funduszu Spójności i Europejskiego Funduszu Morskiego i Rybackiego 
oraz uchylające rozporządzenie Rady (WE) nr 1083/2006, Dziennik Urzędowy Unii Europejskiej 20.12.2013.

Zieliński K., 2006, Przesłanki i konsekwencje procesu modernizacji polskiego rolnictwa, Zeszyty Naukowe Akademii Ekonomicznej w Krakowie, nr 709, Wydawnictwo Akademii Ekonomicznej w Krakowie, Kraków, s. 76-79.

\section{Internet}

[1] https://bdl.stat.gov.pl/BDL/dane/temat (12.04.2016).

[2] http://stat.gov.pl/ (15.04.2016).

[3] https://www.funduszeeuropejskie.2007-2013.gov.pl (13.04.2016).

[4] https://www.funduszeeuropejskie.2007-2013.gov.pl/OrganizacjaFunduszyEuropejskich/Documents/ZPORR_2004_2006.pdf(13.04.2016). 